\title{
THE FEDERAL ROLE IN REGIONAL PLANNING COUNCILS: A COMMENTARY
}

James A. Medeiros

Northeastern University

Let me preface my remarks by making the comment that Professor Glendening has obtained some very useful data through the National Service to Regional Councils. Because of the increasing importance of regional councils of government, particularly in metropolitan areas, any attempts at compiling quantitative data on the operations of these organizations is necessary and praiseworthy. Unfortunately, as I hope to demonstrate later, Professor Glendening has fallen into the trap of making the data suggest more than what they in fact do suggest. This general phenomenon is by no means uncommon in the social sciences, but the mere fact of its continued perpetuation does not color it with legitimacy.

The main purposes of the paper are (1) to demonstrate the desirability of adapting the area-wide approach as a means of solving regional problems, and (2) to note the impact of the federalgovernment in fostering the regional government movement particularly at the metropolitan area. But within this general purposeful framework, something goes askew: Professor Glendening notes that "this paper examines the federal role in the three types of regional councils: (1) councils of governments, (2) economic development districts, and (3) regional planning commissions." Nowhere in the paper does Professor Glendening make any attempt at deciphering the real distinctions between these three diverse forms of regional agencies and appears insistent upon lumping them into one great regional council bag. The most serious shortcoming in this regard is that all three councils are not directly related to the urban problem; and if one is to take the author seriously, the conceptual basis of the paper is in fact the urbanor metropolitan problem. For example, the emphasis in the beginning of the paper is strongly on the writings of such metropolitan experts as Luther Gulick, John Bollens, Henry Schmandt, Victor Jones, Roscoe C. Martin, Robert C. Wood, Edward C. Banfield, and Paul Studenski. In other words, the original perspective of the paper is a strongly metropolitan one; but by some tour de force the author then goes on to treat all three forms of regional councils as a unitary concept when in fact all he can legitimately treat--given his initial perspective in the paper--is the metropolitan councils of governments. Why? Because the metropolitan councils of governments is the only one of the three regional agencies directly related to the metropolitan framework established at length by the author in the first major section of the paper. If in fact the author wished to treat all three diverse and distinct forms of regional councils in toto, then his initial perspective should have been conceptually handled under a broader framework of "regionalism"rather than under some metropolitan configuration.

Apartfrom this gross mis judgement in grouping all three regional manifestations under one framework inappropriately developed, other problems are apparent. The first of these is perhaps a minor one but should not go unchallenged. The author quite clearly in an attempt to bolster the sanctity of regional councils of governments as a most realistic solution to a rea wide problems establishes a "reformist"- "realist" dichotomy which purportedly demonstrates the naive idealism of the former who would hold out for more rigorous structural change in governmental organization in comparison to the "realists" who being pragmatic by nature recognize the limitations of extensive change and opt for more moderate and informal restructuring 
of governments toward solving area-wide problems. In this semantical dichotomy game played by the author, one is left with the impression that the metropolitan structures of Dade County, Nashville, Toronto, and London are not "realistic"; yet the mere fact of their existence should point out their "reality." Or are they only a mirage on the metropolitan scene? ProfessorGlendening inappropriately points out that it is their extensive form which makes them an unrealistic solution; when in many ways the major factor which has contributed to the defeat of extensive governmental jurisdiction at the metropolitan level, has been the ineptitude of the "reformists" in piecing together a public relations program which would make reform understandable to the voting public. Where the "reformists" have put together an extensive public relations campaign, the results have been realistically favorable. I would, however, add one suggestion to the author if he wishes to continue with the dichotomy framework and that is, I would label what the author calls the "realists" as "urban rationalizers"; because that is exactly what the limited-change spokesman do: rationalize sprawl, rationalize limited change, rationalize the status quo, ad absurdum. Much of the rationality is the essence of Lindblom's "muddling through" analysis, and I do not believe that muddling through is appropriate for the 1970's. So, if we're going to play semantics, let's use the right words!

My second major criticismagainst the air of hallowedness that is being given to regional councils of governments is the argument that the re is necessarily a direct causal relationship between the generosity of the federal government and the rise of the councils. I would concur that this may be the case in many regional initiations, but it is still not the major motivation for their establishment. For example, recently an attempt was made by the Mayor of Boston to initiate a council of governments for the Metropolitan Boston area. While the possibility of receiving already depleted federal revenues may loom somewhere in the background, it is not the cause which would give rise to a council of governments for the Boston area. The direct cause instead is an immediate realization that the solution to Boston's problems lies in the need to sustain some form of cooperative governmental arrangements--with or without federal monies. I would suggest, however, that the real cause of regional governments is a contemporary awareness on the part of local governments that the go-it-alone approach is no longer possible. The existence of federal programs and federal monies for regionalism merely reflects this new regional philosophy and did not produce it. In short, I would refute Professor Glendening 's causal analysis with one of my own--and, of course, I am not necessarily any more correct than he. But the important fact is that I do not try to "prove" my causality argument with questionable data. For example, Professor Glendening throughout his paper asserts continually that the federal government is the cause celebré of regionalism and his Table I "proves" this point. But does it? Of the Director's response to the question: "Why was your organization created?", $32 \%$ noted the impact of federal requirements or federal aid. But $31 \%$ say that it was formed because of a recognition for cooperation. Surely, one percentage point is not an adequate standard upon which to base an argument. Indeed, if we combine two of the response categories together (recognition of need for cooperation and serious regional problem to be solved) this would "prove" under the author's interpretation of "proof", that $44 \%$ of the regional agencies were formed to bolster a cooperative attack on regional problems, in comparison to only $32 \%$ formed in order to receive federal aid. The politics of metropolitan areas are in many ways so sensitive and intricate; to assert that these extensive political interests can be reconciled or "bought off" with a federal price tag is a naive generalization. What then are we to make of Tables II and III which show a marked increase in the rise of regional councils at the same time that federal regional programs were 
making their entry? I think the answer lies in my initial argument that the federal government has not "caused" local regionalism but it has merely reflected the new regional philosophy which local governments have developed over the years because of "recognition of a need for cooperation and a serious regional problem to be solved." (Table I categories.)

Other important problems are not really answered by the author, al though the questions are raised. One of these problems is related to the impact of the staffs of the councils of governments in forcing political decis ions because of their expertise. The staff orientation of councils of governments may in fact produce regional governments which are not political bodies at all, and hence unresponsive to public wants. If the author wishes to bolster the image of these regional governments as being realistic, then we should all question the desirability of a realistic government which in fact could produce less responsive government.

Further, I would question the negative view of the future of state government as presented by the author. In many ways, however, the negative view was a necessary result of the orientation of the research undertaken. Whenever one takes it upon himself to "prove" the meritorious aspects of a new creature of federalism, the concomitant result is to castigate the tra ditional. I would argue, however, that if creative federalism is to have any meaning whatsoever, then that is accomplished not by discarding the old in the assault of a questionable new, but perhaps by integrating the best features of both into a state-wide regional framework.

Finally, I would argue that the main criticism of the paper is a tradi tional one in the social sciences: one tends to cut the cloth to meet the needs of preconceived visions and values. If we are to use quantitative data, then we need to be assured that we are not bending the data to prove a point we might subjectively feel quite strongly about but which is not necessarily objectively true. The shortcomings of the paper, however, should not dilute the importance of the author's sincere attempt in raising a discussion about a rather recent but extremely critical feature of government which is bound to increase in use throughout the next decade. 